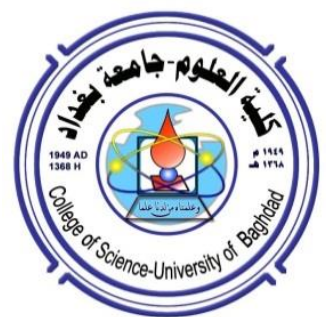

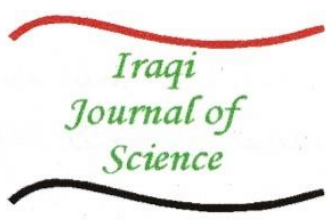

ISSN: 0067-2904

\title{
The Effect of Magnetic Water on The Production and Physiological Traits in The Quail (Coturnix coturnix (Linnaeus, 1758))
}

\author{
Khalid H. Hassan*, Saraa A. Assi, Tabark B. Abdul-Kareem, Zakaria K. Baker \\ Department of Animal Production-College of Agriculture- University of Diyala, Iraq
}

Received: 27/12/2020

Accepted: 18/3/2021

\begin{abstract}
An experiment is conducted to determine the effect of magnetic water on the production performance and blood characteristics of common quail, Coturnix coturnix (Linnaeus, 1758). The experimental treatments included $\mathrm{T} 1=$ control treatment, $\mathrm{T} 2=$ drinking water magnetization at 1000 gauss, $\mathrm{T} 3=$ drinking water magnetization at 1500 gauss, $\mathrm{T} 4=$ diet sprayed with magnetized water 1000 gauss, $\mathrm{T} 5$ = diet sprayed with magnetized water 1500 gauss, each treatment with three replicates. The results showed significant superiority of control group in the body weight, weight gain and feed intake compared with treated groups. The egg shell thickness of T2 showed a significant decrease compared to other groups. The third treatment showed a significant superiority in red blood cell count compared with T1, T4 and T5, while T5 appeared significant reduction in white blood cell count compared with other treatments. There was significant reduction in blood glucose, total protein, cholesterol, and triglyceride in T4 compared with control.
\end{abstract}

Keywords: Magnetic field, poultry, meat production, egg quality, blood traits.

\section{تأثير الماء الممغط في الصفات الانتاجية والففلجية للسمان Linnaeus (Coturnix coturnix)، 1758}

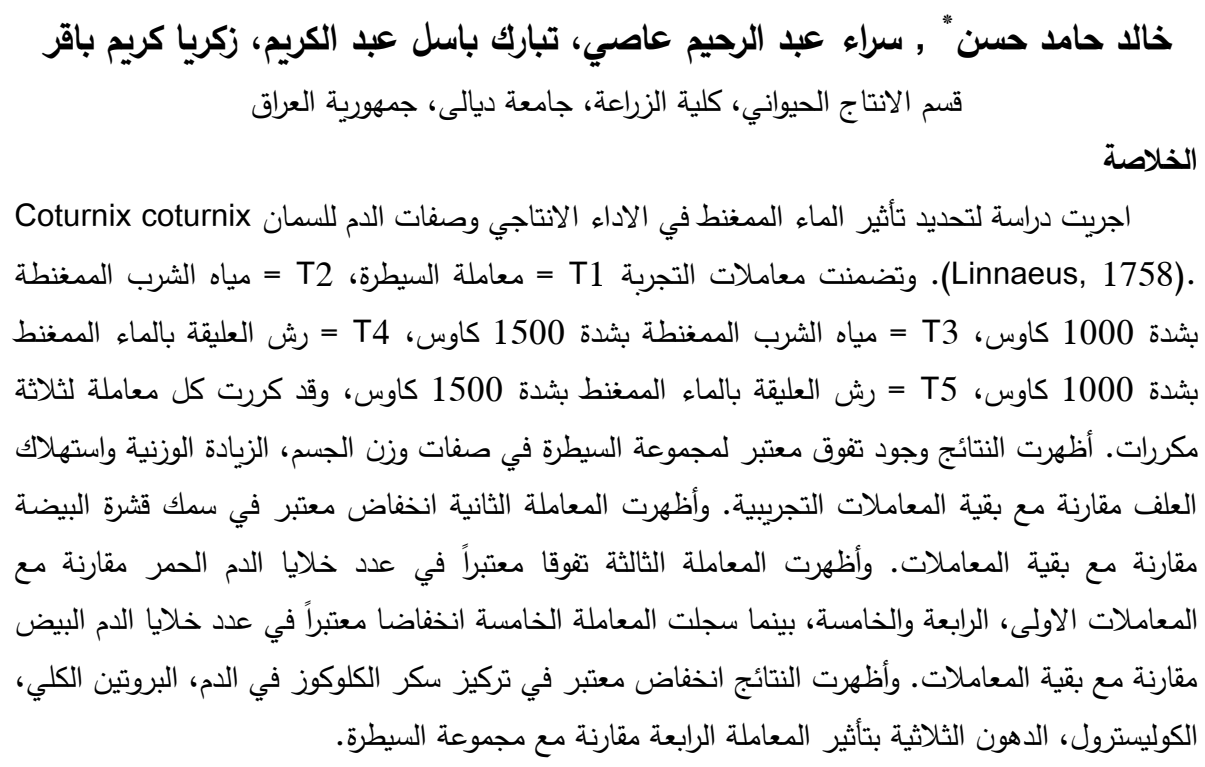

*Email: khaled@agriculture.uodiyala.edu.iq 


\section{Introduction}

Common quail is a small member in poultry, which has unique features to be a research model and laboratory bird due to its early sexual maturity, intensive egg production and low rearing requirements of space $[1,2]$. Quail becoming popular in commercial poultry sector for meat and egg production, due to rapid growth which enable quail to be marketed for consumption at 5-6 weeks of age, short generation interval, high rate of egg laying and much lower feed and space requirements than domestic fowl [3]. Water represents essential part for the life, because of its distribution in live cells to support reactions and biological activities. Also, water has many important features such as holds the magnetic charges and has a dipole moment [4]. Mosin and Ignatov [5] reported that the effect of the magnetic field on water resulted in changes of the structure of hydrated ions, physio-chemical properties and behavior of dissolved inorganic salts. Wang et al. [6] reported that water passing through a magnetic field changes water to a magnetic water, as a result of these exposure to the magnetic field could enhance the conductivity, decrease the surface tension of water, increase of evaporation amount and decrease of specific heat and boiling point after magnetization. In related study, Lin and Yotvat [7] reported that using magnetic water for drinking in animal husbandry result an increase of milk production and wool in sheep and high weight gain in geese and increase egg production and hatchability in turkey. In other hand, medical and healthcare studies used the chicken embryos as an animal model to investigate the effect of low frequency electromagnetic fields on the growth and the embryonic development [8]. Also, Alhassani and Amin [9] recorded no significant effect of drinking magnetic water in performance of broiler chicken. So, there are no stable trend on the effect of magnetic water on animal production.

People may be directly exposed to electromagnetic fields by using electric devices or nearby high voltage electricity network among stations, or indirect exposure to magnetic fields through drinking magnetic water or eating food that have been exposed to magnetic field, so magnetic exposure may be have adverse effects on the public health[10]. There were many studies concerned with adverse psychological effects due to the consequences exposures to electromagnetic fields, from the early studies, Wertheimer and Leeper [11] reported that environmental exposure to electric and magnetic fields $(50$ and $60 \mathrm{~Hz})$ might increase the risk of chronic disease and death due to cancer in children. In other study, Reichmanis et al. [10] suggested a correlation between electromagnetic fields and suicide. At the cell level, Barnes and Greenebaum [12] suggested that the initial effect of magnetic take place at the cell membrane and an organelle's membrane such as mitochondria or endoplasmic reticulum and change the conformations of receptors and ion channels, which are fundamental processes of cell are affected immediately. Blackman et al. [13] reported changes in calcium ion efflux across chicks' brain tissue cell membranes as a response to magnetic fields exposure. Ozguner et al. [14] recorded negative effects of frequency $900 \mathrm{MHz}$ on the reproductive organs and tissues, changing the balance of reproductive hormones (including testosterone, progesterone, LH and FSH) in mammals. Ghodbane et al. [15] reported that exposure to magnetic field can increase the activity, concentration, and life time of paramagnetic free radicals, which might result oxidative stress, mutation, and apoptosis.

The current study aims to investigate the effect of using magnetic water result from multiple magnetic fields on some production traits and blood profile of common quail.

\section{Material and Methods}

\subsection{The study site}

The study conducted at the poultry farm in the Department of Animal production- College of Agriculture- University of Diyala, in the Province of Diyala, Iraq. The mean temperature during autumn season (The study period) ranges between 15 to $38 \stackrel{0}{\mathrm{C}}$. The annual rainfall ranges between 5 to $25 \mathrm{~mm}$. 


\subsection{Management}

Birds housed in cages with $40 \times 50 \mathrm{~cm}$ per 10 unsexed birds for total flock consist of 150 birds, during the experiment period. Water and diet introduced to birds freely. The diet formula contents crude protein during the growing period (1-42 days) was $24.15 \%$ and metabolic energy $2780 \mathrm{Kcal} / \mathrm{Kg}$, and the production diet that used after 42 days of age contents crude protein $20.21 \%$ and metabolic energy $2832.3 \mathrm{Kcal} / \mathrm{Kg}$ according to NRC [16]. 2.3. Treatments and Birds

Experiment conducted to determine the effect of magnetic water (treated with six repeated magnetic fields), using two magnetic intensities including 1000 or 1500 gauss using laboratory magnetic instrument [17]. The experimental treatments consist of control group represent untreated tap water (T1), magnetic drinking water with 1000 gauss (T2) or 1500 gauss (T3), moistening the diet with magnetized water of 1000 gauss (T4) or 1500 gauss (T5). The experimental flock consist of 150 chicks (one day old) of quails, which distributed randomly on five treatments (30 birds / treatment). The experimental period was six weeks, and the measurements recorded for meat production traits including body weight, weight gain, feed conversion, carcass weight, dress percentage, vital organs (Heart and Liver weight), egg quality traits and blood parameters.

\subsection{Statistical Analysis}

The experiment performed according to completely randomized design (CRD), and the data analyzed using general linear model by SPSS version 26 software. The significant differences among means of groups detected by Tukey test at $\mathrm{P} \leq 0.05$.

\section{Results and Discussion}

The mean of live body weight, weight gain, feed intake and feed conversion of different experimental treatments is presented in Table 1. The statistical analysis shows significant differences among treatments in live body weight, weight gain and feed intake while there were no significant differences in feed conversion, hence the control treatment recorded significant high body weight compared with T3, T4 and T5. The weight gain and feed intake recorded significant decline in T4 and T5 compared with control group. The results reflect the harmful effects of magnetic water on the biological systems of quail result as a depression in feed intake and live body weight. The results disagreed with Lin and Yotvat [7]; Alhassani and Amin [9] may be due to the differences in animal species as well as the method of magnetization of water in treatment, hence the current study treated water with multiple magnetic fields. The live body weight recorded in the control treatment of recent study (177.53 gram) was heavier than live body weight recorded by Fadhil and Hassan [18] at six weeks of age (127.21 gram), may be due to the differences in the management of flocks.

Table 1-Means \pm Standard Error of body weight, weight gain, feed intake and feed conversion in experimental groups of the quails.

\begin{tabular}{ccccc}
\hline Groups & Body weight (g.) & Weight gain (g.) & Feed intake (g.) & Feed conversion \\
\hline T1 & $177.53 \pm 3.66 \mathrm{a}$ & $168.30 \pm 3.61 \mathrm{a}$ & $715.61 \pm 30.37 \mathrm{a}$ & $4.26 \pm 0.23$ \\
T2 & $170.58 \pm 1.66 \mathrm{ab}$ & $161.77 \pm 1.40 \mathrm{ab}$ & $651.72 \pm 12.67 \mathrm{ab}$ & $4.02 \pm 0.09$ \\
T3 & $164.12 \pm 1.79 \mathrm{bc}$ & $156.14 \pm 2.09 \mathrm{abc}$ & $675.32 \pm 28.77 \mathrm{ab}$ & $4.32 \pm 0.13$ \\
T4 & $158.73 \pm 1.37 \mathrm{bc}$ & $150.22 \pm 1.40 \mathrm{bc}$ & $591.74 \pm 32.86 \mathrm{~b}$ & $3.94 \pm 0.23$ \\
T5 & $157.04 \pm 6.76 \mathrm{c}$ & $148.37 \pm 7.10 \mathrm{c}$ & $601.66 \pm 11.30 \mathrm{~b}$ & $4.06 \pm 0.12$ \\
\hline
\end{tabular}

T1: control, T2: drink water 1000 gauss, T3: drink water 1500 gauss, T4: diet sprayed with 1000 gauss water, T5: diet sprayed with 1500 gauss water.

Means have different letters refer to significant difference at $\mathrm{P} \leq 0.05$ according Tukey test.

The means of carcass weight, dress percentage and liver weight showed no significant differences among treatments (Table 2), while the percentage heart weight recorded significant difference between $\mathrm{T} 3$ and $\mathrm{T} 4$. 
Table 2-Means \pm Standard Error of carcass weight, dress percentage, heart weight and liver weight in experimental groups of the quails

\begin{tabular}{ccccc}
\hline Groups & $\begin{array}{c}\text { Carcass weight } \\
(\mathrm{g} .)\end{array}$ & $\begin{array}{c}\text { Dress percentage } \\
(\%)\end{array}$ & $\begin{array}{c}\text { Heart weight } \\
(\%)\end{array}$ & $\begin{array}{c}\text { Liver weight } \\
(\%)\end{array}$ \\
\hline T1 & $110.86 \pm 2.57$ & $66.73 \pm 1.10$ & $0.90 \pm 0.03 \mathrm{ab}$ & $2.66 \pm 0.27$ \\
T2 & $114.22 \pm 6.20$ & $62.75 \pm 2.79$ & $0.89 \pm 0.04 \mathrm{ab}$ & $2.70 \pm 0.28$ \\
T3 & $112.41 \pm 5.87$ & $67.32 \pm 1.77$ & $1.01 \pm 0.03 \mathrm{a}$ & $2.45 \pm 0.36$ \\
T4 & $110.68 \pm 5.66$ & $64.99 \pm 1.09$ & $0.79 \pm 0.02 \mathrm{~b}$ & $2.88 \pm 0.32$ \\
T5 & $103.85 \pm 4.72$ & $63.52 \pm 1.56$ & $0.92 \pm 0.06 \mathrm{ab}$ & $2.86 \pm 0.06$ \\
\hline
\end{tabular}

T1: control, T2: drink water 1000 gauss, T3: drink water 1500 gauss, T4: diet sprayed with 1000 gauss water, T5: diet sprayed with 1500 gauss water.

Means have different letters refer to significant difference at $\mathrm{P} \leq 0.05$ according Tukey test.

The carcass weight and dress percentage values of recent study agreed with Hassan et al. [19] who reported $110.08 \mathrm{~g}$. for carcass weight and $65.65 \%$ for dress percentage.

The results recorded significant differences between $\mathrm{T} 1$ and $\mathrm{T} 4$ in the body weight at sexual maturity, while there were no significant differences among other treatments. Also, there were no significant differences among treatments in the age at sexual maturity which ranged 39.00 - 44.66 days in the groups (Table 4).

Table 3- Means \pm Standard Error of age at sexual maturity, body weight at sexual maturity in experimental groups of the quails.

\begin{tabular}{ccc}
\hline Groups & Age at sexual maturity(day) & Body weight at sexual maturity (g.) \\
\hline T1 & $39.00 \pm 0.00$ & $149.43 \pm 16.70 \mathrm{~b}$ \\
T2 & $42.66 \pm 2.02$ & $185.05 \pm 8.66 \mathrm{ab}$ \\
T3 & $41.11 \pm 0.57$ & $181.10 \pm 9.03 \mathrm{ab}$ \\
T4 & $44.33 \pm 2.66$ & $192.09 \pm 7.80 \mathrm{a}$ \\
T5 & $44.66 \pm 2.33$ & $181.55 \pm 7.80 \mathrm{ab}$ \\
\hline
\end{tabular}

T1: control, T2: drink water 1000 gauss, T3: drink water 1500 gauss, T4: diet sprayed with 1000 gauss water, T5: diet sprayed with 1500 gauss water.

Means have different letters refer to significant difference at $\mathrm{P} \leq 0.05$ according Tukey test.

The magnetic water treatments effect significantly in the egg quality traits including shell thickness, albumin weight, albumin height and yolk color (Table 4).

Table 4-Means \pm Standard Error of egg quality traits in experimental groups of the quails

\begin{tabular}{ccccc}
\hline Groups & $\begin{array}{c}\text { Albumin weight } \\
(\mathrm{g} .)\end{array}$ & $\begin{array}{c}\text { Shell thickness } \\
(\mathrm{mm} .)\end{array}$ & $\begin{array}{c}\text { Albumin height } \\
(\mathrm{mm})\end{array}$ & Yolk color \\
\hline T1 & $5.45 \pm 0.23 \mathrm{ab}$ & $0.30 \pm 0.01 \mathrm{a}$ & $5.47 \pm 0.14 \mathrm{a}$ & $2.87 \pm 0.39 \mathrm{ab}$ \\
T2 & $5.56 \pm 0.08 \mathrm{ab}$ & $0.27 \pm 0.01 \mathrm{~b}$ & $4.86 \pm 0.18 \mathrm{~b}$ & $2.42 \pm 0.36 \mathrm{~b}$ \\
T3 & $5.76 \pm 0.22 \mathrm{a}$ & $0.31 \pm 0.01 \mathrm{a}$ & $5.08 \pm 0.17 \mathrm{ab}$ & $2.66 \pm 0.21 \mathrm{ab}$ \\
T4 & $5.04 \pm 0.13 \mathrm{~b}$ & $0.30 \pm 0.01 \mathrm{a}$ & $4.90 \pm 0.25 \mathrm{ab}$ & $2.55 \pm 0.24 \mathrm{ab}$ \\
T5 & $5.66 \pm 0.24 \mathrm{a}$ & $0.30 \pm 0.01 \mathrm{a}$ & $5.30 \pm 0.05 \mathrm{ab}$ & $3.42 \pm 0.20 \mathrm{a}$ \\
\hline
\end{tabular}

T1: control, T2: drink water 1000 gauss, T3: drink water 1500 gauss, T4: diet sprayed with 1000 gauss water, T5: diet sprayed with 1500 gauss water.

Means have different letters refer to significant difference at $\mathrm{P} \leq 0.05$ according Tukey test.

Hence the shell thickness of eggs of $\mathrm{T} 2$ recorded significant decline compared with other treatments, while there was a significant decline in albumin weight of T4 compared with T3 and T5. The yolk color in T5 appeared significant high score compared with T2.

The blood profile of magnetic water groups shows significant changes in RBC, WBC, Hb. Table 5 represents blood parameters of the experimental groups, which recorded significant superiority of T3 in RBC and WBC compared with T1 and T5. 
Table 5-Red blood cells, White blood cells, Hemoglobin and Package cell volume in experimental groups of the quail (Means \pm S.E.).

\begin{tabular}{ccccc}
\hline Groups & $\begin{array}{c}\text { Red Blood Cells } \\
\times 10^{6} / \mathrm{mm}^{3}\end{array}$ & $\begin{array}{c}\text { White Blood } \\
\text { Cells } \times 10^{3} / \mathrm{mm}^{3}\end{array}$ & $\begin{array}{c}\text { Hemoglobin } \\
(\mathrm{g} / \mathrm{dl})\end{array}$ & $\begin{array}{c}\text { PCV } \\
(\%)\end{array}$ \\
\hline T1 & $3.78 \pm 0.06 \mathrm{c}$ & $24.58 \pm 0.07 \mathrm{~b}$ & $11.52 \pm 0.74 \mathrm{ab}$ & $36.67 \pm 2.20 \mathrm{ab}$ \\
T2 & $4.64 \pm 0.18 \mathrm{ab}$ & $26.48 \pm 0.15 \mathrm{a}$ & $10.73 \pm 0.45 \mathrm{~b}$ & $34.33 \pm 1.33 \mathrm{~b}$ \\
T3 & $4.74 \pm 0.06 \mathrm{a}$ & $26.90 \pm 0.25 \mathrm{a}$ & $13.03 \pm 0.44 \mathrm{ab}$ & $41.17 \pm 1.30 \mathrm{ab}$ \\
T4 & $4.11 \pm 0.24 \mathrm{bc}$ & $26.98 \pm 0.32 \mathrm{a}$ & $13.68 \pm 0.42 \mathrm{a}$ & $43.17 \pm 1.22 \mathrm{a}$ \\
T5 & $3.89 \pm 0.03 \mathrm{c}$ & $24.95 \pm 0.24 \mathrm{~b}$ & $11.97 \pm 0.67 \mathrm{ab}$ & $38.00 \pm 1.98 \mathrm{ab}$ \\
\hline
\end{tabular}

T1: control, T2: drink water 1000 gauss, T3: drink water 1500 gauss, T4: diet sprayed with 1000 gauss water, T5: diet sprayed with 1500 gauss water.

Means have different letters refer to significant difference at $\mathrm{P} \leq 0.05$ according Tukey test.

Table 6 shows significant superiority of T2 compared with control in basophiles, while control group appeared low percentage compared with T3 and T4 groups. The different groups had no significant differences in monocytes.

Table 6-Basophiles, Eosinophil and Monocytes (\%) in experimental groups of the quail (Means \pm S.E.)

\begin{tabular}{cccc}
\hline Groups & Basophiles & Eosinophil & Monocytes \\
\hline T1 & $1.35 \pm 0.06 \mathrm{~b}$ & $1.25 \pm 0.07 \mathrm{~b}$ & $2.66 \pm 0.06$ \\
T2 & $1.65 \pm 0.09 \mathrm{a}$ & $1.64 \pm 0.10 \mathrm{ab}$ & $2.61 \pm 0.05$ \\
T3 & $1.56 \pm 0.06 \mathrm{ab}$ & $1.78 \pm 0.08 \mathrm{a}$ & $2.57 \pm 0.08$ \\
T4 & $1.44 \pm 0.02 \mathrm{ab}$ & $1.81 \pm 0.05 \mathrm{a}$ & $2.72 \pm 0.05$ \\
T5 & $1.41 \pm 0.07 \mathrm{ab}$ & $1.45 \pm 0.16 \mathrm{ab}$ & $2.60 \pm 0.06$ \\
\hline
\end{tabular}

T1: control, T2: drink water 1000 gauss, T3: drink water 1500 gauss, T4: diet sprayed with 1000 gauss water, T5: diet sprayed with 1500 gauss water.

Means have different letters refer to significant difference at $\mathrm{P} \leq 0.05$ according Tukey test.

All treated groups showed significant decline in heterophils percentage compared with control group (Table 7), while reverse situation observed with lymphocytes hence the results pointed significant low lymphocytes percentage in control group compared with treated groups, this case may be reflect the positive response of spleen, thymus and payer's batches to the magnetic water treatment which improve the production of antibodies in the immunity system.

Table 7-Heterophils, Lymphocytes (\%) and H/L ratio in experimental groups of the quail (Means \pm S.E.)

\begin{tabular}{cccc}
\hline Groups & Heterophils & Lymphocytes & H/L \\
\hline T1 & $32.89 \pm 0.27 \mathrm{a}$ & $61.85 \pm 0.22 \mathrm{c}$ & $0.40 \pm 0.01$ \\
T2 & $22.37 \pm 0.31 \mathrm{c}$ & $71.76 \pm 0.34 \mathrm{a}$ & $0.37 \pm 0.01$ \\
T3 & $22.83 \pm 0.25 \mathrm{bc}$ & $71.27 \pm 0.27 \mathrm{ab}$ & $0.38 \pm 0.00$ \\
T4 & $22.72 \pm 0.14 \mathrm{bc}$ & $71.32 \pm 0.20 \mathrm{ab}$ & $0.38 \pm 0.01$ \\
T5 & $27.19 \pm 2.43 \mathrm{~b}$ & $67.34 \pm 2.18 \mathrm{~b}$ & $0.37 \pm 0.02$ \\
\hline
\end{tabular}

T1: control, T2: drink water 1000 gauss, T3: drink water 1500 gauss, T4: diet sprayed with 1000 gauss water, T5: diet sprayed with 1500 gauss water.

The results in Table 8 pointed significant low values of glucose in T2 and T4 (low magnetic intensity) compared with control group, while this effect disappeared among T3, T5 (high magnetic intensity) and control group. This case may be pointed to the sensitivity of glucose level to the water exposure magnetic intensity value, that may lead to confirm the previous mentioned studies about the effect of magnetic fields on water solubility [20] and 
substance permeability across cell membrane [21,22], and the benefits in both prevention and treatment of complications in diabetic patients [23]. The results recorded significant low values of cholesterol and triglyceride in all magnetic water treatments compared to control group, the results agreed with Al-Hilali [20], while the recent study recorded decline in triglyceride of magnetic water groups in T2, T3 and T4 treatment compared to control, these results contradict with results recorded by Al-Hilali [20].

Table 8-Glucose, Plasma protein, Cholesterol and Triglyceride in experimental groups of the quail (Means \pm S.E.)

\begin{tabular}{ccccc}
\hline Groups & $\begin{array}{c}\text { Glucose } \\
(\mathrm{g} / \mathrm{L})\end{array}$ & $\begin{array}{c}\text { Plasma protein } \\
(\mathrm{g} / \mathrm{L})\end{array}$ & $\begin{array}{c}\text { Cholesterol } \\
(\mathrm{mg} / \mathrm{dl})\end{array}$ & $\begin{array}{c}\text { Triglyceride } \\
(\mathrm{mg} / \mathrm{dl})\end{array}$ \\
\hline T1 & $205.07 \pm 2.50 \mathrm{a}$ & $5.41 \pm 0.12 \mathrm{a}$ & $211.81 \pm 2.08 \mathrm{a}$ & $289.03 \pm 5.22 \mathrm{a}$ \\
T2 & $196.74 \pm 1.45 \mathrm{bc}$ & $3.49 \pm 0.14 \mathrm{c}$ & $125.47 \pm 2.26 \mathrm{~d}$ & $189.16 \pm 2.21 \mathrm{c}$ \\
T3 & $207.56 \pm 1.64 \mathrm{a}$ & $4.57 \pm 0.07 \mathrm{~b}$ & $153.87 \pm 2.37 \mathrm{c}$ & $237.44 \pm 3.93 \mathrm{~b}$ \\
T4 & $190.86 \pm 1.85 \mathrm{c}$ & $4.60 \pm 0.07 \mathrm{~b}$ & $133.07 \pm 2.41 \mathrm{~d}$ & $237.18 \pm 5.22 \mathrm{~b}$ \\
T5 & $203.46 \pm 1.65 \mathrm{ab}$ & $5.26 \pm 0.11 \mathrm{a}$ & $201.87 \pm 1.83 \mathrm{~b}$ & $255.40 \pm 5.47 \mathrm{~b}$ \\
\hline
\end{tabular}

T1: control, T2: drink water 1000 gauss, T3: drink water 1500 gauss, T4: diet sprayed with 1000 gauss water, T5: diet sprayed with 1500 gauss water.

Means have different letters refer to significant difference at $\mathrm{P} \leq 0.05$ according Tukey test.

\section{Conclusion}

Using magnetic drink water or spraying the diet with magnetized water of 1000 or 1500 gauss resulted in a significant decrease in the characteristics of meat production in the quail, and at the same time an increase in the body weight at sexual maturity, in other hand, there was an increased value in blood parameters including $\mathrm{RBC}, \mathrm{WBC}$ and $\mathrm{Hb}$, and these changes gave an indicator for viable fitness result from exposure to experimental levels of magnetic field.

\section{References}

[1] J. Kaye, G. N. Akpa, I. A. Adeyinka and B. I. Nwagu, "Estimates of Genetic Parameters For Body Weight and Some Economic Important Traits in The Japanese Quail (Conturnix Conturnix Japonica)", Research Journal of Agriculture, vol. 3, pp. 1-15, 2017.

[2] K. H. Hassan, Poultry Breeding. Univ. of Diyala Press. Iraq, 2011, p. 290.

[3] K. H. Hassan and M. A. Fadhil, "Genetic Selection for Body Weight in Japanese Quail (Coturnix Coturnix Japonica) Under Different Nutritional Environments“, Adv. Anim. Vet. Sci., vol. 7, no.7, pp. 526-529, 2019.

[4] K. Khudiar and A. M. Ali, 2012, "Effect of Magnetic Water on Some Physiological Aspects of Adult Male Rabbits", In Proceeding of the Eleventh Veterinary Scientific Conference,pp.120-126.

[5] O. Mosin and I. Ignatov, "Basic Concepts of Magnetic Water Treatment", European Journal of Molecular Biotechnology, vol. 4, no. 2, pp. 72-85, 2014.

[6] Y. Wang, H. Wei and Z. Li, "Effect of Magnetic Field on The Physical Properties of Water", Results in Physics, vol. 8, pp. 262-267, 2018.

[7] I. J. Lin and J. Yotvat, "Exposure of Irrigation and Drinking Water to A Magnetic Field With Controlled Power and Direction", Journal of Magnetism and Magnetic Materials, vol. 83, pp. 525-526, 1990.

[8] M. S. Lahijani, S. E. Nojooshi and S. F. Siadat, "Light and Electron Microscope Studies Of Effects of $50 \mathrm{~Hz}$ Electromagnetic Fields on Pre-Incubated Chick Embryo", Electromagnetic Biology and Medicine, vol. 26, pp. 83-98, 2007

[9] D. H. Alhassani and G. S. Amin, "Response of Some Productive Traits of Broiler Chickens To Magnetic Water", International Journal of Poultry Science, vol. 11, pp. 158-160, 2012.

[10] M. Reichmanis, F. S. Perry, A. A. Marin and R. O. Becker, "Relationship Between Suicide And The Electromagnetic Field of Overhead Power Lines", Physiol. Chem. Phys., vol. 11, pp. 395404, 1979. 
[11] N. Wertheimer and E. Leeper, "Electrical Wiring Configurations and Childhood Cancer", Am. J. Epidemiol., vol. 109, pp. 273-284, 1979.

[12] F. S. Barnes and B. Greenebaum, Biological and Medical Aspects of Electromagnetic Fields, CRC press, 2019, pp. 439.

[13] C. F. Blackman, S. G. Benane, L. S. Kinney, W. T. Joines and D. E. House, "Effects of ELF Fields On Calcium-Ion Efflux", Radiat. Res., vol. 92, pp. 510-520, 1982.

[14] M. Ozguner, A. Koyu, G. Cesur, M. Ural, F. Ozguner, A. Gokcimen and N. Delibas, "Biological and Morphological Effects on The Reproductive Organ of Rats After Exposure To Electromagnetic Fields", Saudi Med. J. vol. 26, no. 3, pp. 405-410, 2005.

[15] G. Ghodbane, A. Lahbib, M. Sakly and H. Abdelmelek, "Bio-Effects of Static Magnetic Fields:Oxidative Stress, Genotoxic Effects, And Cancer Studies“, BioMed Research International, dx.doi.org/10.1155/2013/602987, 2013.

[16] National Research Council (NRC) 1994, " Nutrient Requirement of Poultry", $9^{\text {th }}$ Ed. National Academy press, Washington, 1994, p. 157.

[17] K. H. Hassan, "Innovation of Laboratory Instrument for Magnetize Water and Solutions", Patent No. 6212. Iraq. 2020.

[18] M. A. Fadhil and K. H. Hassan, "Divergent Genetic Selection for Body Weight at Four Weeks Age in Japanese Quail", Journal of Global Pharma. Technology, vol. 10, no. 11, pp. 612616, 2018.

[19] K. H. Hassan, A. Ahmad, A. A. Fadil and N. K. Dawood, "Study of Dress Percentage And Relative Weights of Carcass Parts in Various Ages of Japanese Quail in Iraq", Diyala Journal of Agricultural Sciences, vol. 5, no. 2, pp. 92-103, 2013.

[20] A. Al-Hilali,"Effect of Magnetically Treated Water on Physiological and Biochemical Blood Parameters of Japanese Quail", Int. J. Poult. Sci., vol. 17, pp. 78-84, 2018.

[21] B. Gonet, "Influence of Constant Magnetic Fields on Certain Physiochemical Properties Of Water", Bioelectromagnetics: Journal of the Bioelectromagnetics Society, vol. 6, no. 2, pp. 169$175,1985$.

[22] V. V. Lednev, "Possible Mechanism for The Influence of Weak Magnetic Fields on Biological Systems", Bioelectromagnetics, vol. 12, no. 2, pp. 71-75, 1991.

[23] H. J. Lee and M. H. Kang, "Effect of The Magnetized Water Supplementation on Blood Glucose,

[24] Lymphocyte DNA Damage, Antioxidant Status, And Lipid Profiles In STZ-Induced Rats", Nutrition Research and Practice, vol. 7, no. 1, pp. 34-42, 2013. 